\title{
Proses Berpikir Kritis Siswa Kelas VII F Mts. Al-Qodiri 1 Jember dalam Pemecahan Masalah Matematika Pokok Bahasan Segitiga dan Segi Empat ditinjau dari Adversity Quotient (The Process of Critical Thinking Students Class VII F Mts. Al-Qodiri 1 Jember in Problem Solving on Chapter Triangle and Quadrilateral Reviewed by Adversity Quotient)
}

\author{
Suci Rohmatul Hidayah, Dinawati Trapsilasiwi, Susi Setiawani \\ Pendidikan Matematika, Fakultas Keguruan dan Ilmu Pendidikan, Universitas Jember (UNEJ) \\ Jln. Kalimantan 37, Jember 68121 \\ E-mail: suci.rohmatul@gmail.com
}

\begin{abstract}
Abstrak
Penelitian ini bertujuan untuk mendeskripsikan proses berpikir kritis siswa climber, camper, dan quitter di kelas VII F MTs al-Qodiri 1 Jember dalam memecahkan masalah matematika pokok bahasan segitiga dan segi empat sesuai dengan indikator proses berpikir kritis yang telah disusun. Instrumen yang digunakan dalam penelitian ini adalah angket Adversity Response Profile (ARP), soal tes kemampuan berpikir kritis dan pedoman wawancara. Penentuan subyek dilakukan menggunakan teknik snowball sampling. Subyek penelitian adalah enam orang siswa yang mewakili setiap kategori Adversity Quotient. Berdasarkan analisis data yang dilakukan dari hasil penelitian menunjukkan bahwa subyek 1 dan 2 (siswa climber) melalui semua indikator berpikir kritis dalam menyelesaikan setiap tes yang diberikan sehingga diperoleh solusi pemecahan yang tepat. Subyek 3, 4, dan 5 (Siswa camper) hanya mampu melalui tahap klarifikasi dan Assessment dalam menyelesaikan permasalahan yang diberikan, sehingga solusi pemecahan masalah yang diberikan kurang tepat. Sedangkan subyek 6 (Siswa quitter), hanya mampu memenuhi tahap klarifikasi dalam menyelesaikan permasalahan yang diberikan
\end{abstract}

Kata Kunci: berpikir kritis, tahapan berpikir kritis Jacob dan Sam, adversity quotient

\section{Abstract}

The aim of this research was to describe the critical thinking process of climber, camper, and quitter students in grade VII $F$ of MTs Al-Qodiri 1 Jember in solving the problems on triangles and rectangles according to indicators of critical thinking process that has been compiled. The instruments used in this research were adversity response profile questionnaire (ARP), critical thinking skills test, and interview guidelines. The subjects of the research were taken by using the snowball sampling technique. The subjects of the research were six students that represent each category of adversity quotient. Based on the data analysis of the research's results show that subjects 1 and 2 (climber students) through all of the critical thinking indicators in solving any given test in order to obtain appropriate solutions. Subject 3, 4, and 5 (camper students) was only able to pass through stages of clarification and assessment in solving the problems, thus solving the problem given less precise. While subject 6 (quitter student), only able to meet the clarification stage in solving the problems that have been given.

Keywords : critical thinking, stages of critical thinking by Jacob and Sam, adversity quotient

\section{Pendahuluan}

Pendidikan mempunyai peranan yang sangat penting dalam upaya peningkatan sumber daya manusia. Matematika merupakan salah satu mata pelajaran yang menduduki peranan penting dalam dunia pendidikan, karena matematika adalah salah satu ilmu pengetahuan dasar di berbagai disiplin ilmu yang mengembangkan daya pikir manusia. Selain itu, matematika juga merupakan mata pelajaran yang wajib diberikan pada setiap jenjang pendidikan. Melalui mata pelajaran matematika, aljabar mulai diperkenalkan kepada siswa ditingkat Sekolah Menengah Pertama (SMP) [5]. Meskipun matematika dijenjang SMP mempunyai jam pelajaran yang relatif banyak, kenyataan menunjukkan bahwa saat ini masih banyak peserta didik yang belum bisa mencapai target sesuai dengan tujuan pendidikan nasional. Matematika sering kali dianggap pelajaran yang menakutkan bahkan pelajaran yang sangat dibenci bagi sebagian besar peserta didik. Salah satu penyebabnya yaitu proses pembelajaran lebih sering berlangsung satu arah atau terpusat pada guru (teacher centered). Beberapa guru belum memberikan kebebasan berpikir kepada peserta didik sehingga mayoritas peserta didik pergi ke sekolah hanya untuk mendengarkan penjelasan guru dan mencatat apa yang dituliskan guru tanpa mencoba memahami materi yang diajarkan. Apabila hal ini terus dibiarkan, peserta didik tidak akan dapat berkembang karena proses berpikir mereka dibatasi.

Berpikir kritis merupakan proses disiplin secara intelektual, karena seseorang secara aktif dan terampil memahami, mengaplikasikan, menganalisis, mensintesakan 
dan mengevaluasi berbagai informasi yang dia kumpulkan atau yang dia ambil dari pengalaman, pengamatan, refleksi yang dilakukannya, serta penalaran atau komunikasi yang dilakukannya. Dewey [3], menamakan berpikir kritis sebagai 'berpikir reflektif' yaitu suatu pertimbangan yang aktif, persistent (terus-menerus), dan teliti mengenai sebuah keyakinan atau bentuk pengetahuan yang diterima begitu saja dipandang dari sudut alasan-alasan yang mendukungnya dan kesimpulan-kesimpulan lanjutan yang menjadi kecenderungannya.

Proses berpikir kritis merupakan suatu rangkaian tahaptahap berpikir dalam memecahkan masalah sehingga diperoleh solusi yang tepat. Jacob dan Sam [4] mendefinisikan 4 tahapan proses berpikir kritis, yaitu klarifikasi, assessment, inferensi, dan strategi. Uraian dari keempat tahapan tersebut sebagai berikut.

\section{a. Klarifikasi}

klarifikasi merupakan tahap di mana siswa merumuskan masalah dengan tepat dan jelas. Merumuskan masalah dengan tepat dan jelas dapat dilakukan dengan menemukan informasi apa saja yang diberikan dan pertanyaan apa yang diajukan dalam permasalahan tersebut.

\section{b. Assessment}

Assessment merupakan tahap di mana siswa menemukan yang penting dalam masalah. Dalam menemukan bagian yang terpenting dalam masalah, siswa harus mengumpulkan dan menilai informasi yang relevan, meminta alasan dari setiap bukti yang diberikan relevan atau tidak, serta membuat pertimbangan nilai dari argumen yang diberikan.

\section{c. Inferensi}

Inferensi merupakan tahap dimana siswa membuat kesimpulan berdasarkan informasi yang telah diperoleh. Informasi-informasi yang relevan selanjutnya digunakan dalam pemecahan masalah dengan memperhatikan hubungan tiap informasi tersebut.

\section{d. Strategi}

Strategi merupakan tahap dimana siswa berpikir secara terbuka dalam menyelesaikan masalah. Tahap ini, siswa mulai mengusulkan langkah spesifik yang mengarah ke solusi, mendiskusikan langkah-langkah yang mungkin, mengevaluasi langkah-langkah pemecahan masalah tersebut, dan memprediksi hasil dari langkah-langkah pemecahan masalah yang telah diusulkan.

Proses pemecahan masalah tidak hanya melibatkan kemampuan berpikir saja, namun juga memerlukan usaha keras untuk mengatasi kesulitan-kesulitan yang ada. Adversity Quotient (AQ) merupakan suatu kecerdasan atau kemampuan dalam mengubah, mengolah sebuah permasalahan atau kesulitan, dan menjadikannya sebuah tantangan untuk diselesaikan. Stoltz mengelompokkan orang dalam 3 kategori AQ, yaitu quitter (AQ rendah ), camper (AQ sedang) dan climber (AQ tinggi). Quitters merupakan kelompok orang yang kurang memiliki kemauan untuk menerima tantangan dalam hidupnya. Campers merupakan kelompok orang yang sudah memiliki kemauan untuk berusaha menghadapi masalah dan tantangan yang ada, namun mereka berhenti karena merasa tidak mampu lagi. Sedangkan climbers merupakan kelompok orang yang memilih untuk terus berjuang menghadapi berbagai macam hal yang akan terus menerjang baik berupa masalah, tantangan, hambatan, serta hal lain yang terus didapat setiap harinya.

Seseorang harus memiliki kecerdasan adversitas yang tinggi serta kemampuan berpikir kritis yang baik agar dapat menyelesaikan setiap permasalahan yang ada. Fruner dan Robinson [7] menyatakan bahwa untuk meningkatkan kemampuan berpikir kritis matematis, pembelajaran harus difokuskan pada pemahaman konsep dengan berbagai pendekatan daripada keterampilan prosedural. Oleh karena itu, pokok bahasan segitiga dan segi empat dipilih dalam penelitian ini karena selain pokok bahasan tersebut berpengaruh terhadap pembentukan konsep lainnya seperti bangun ruang sisi datar, masalah-masalah dalam pokok bahasan tersebut dianggap dapat melatih kemampuan berpikir kritis siswa.

Berdasarkan penelitian yang telah dilakukan oleh ambarwati et al. [1], proses berpikir kritis peserta didik dalam menyelesaikan permasalahan memiliki perbedaan antara setiap individu. Hal ini karena peserta didik memiliki kecerdasan yang berbeda sehingga mempengaruhi proses berpikir kritisnya. Menurut Stoltz [6], agaknya bukan IQ ataupun EQ yang menentukan suksesnya seseorang, ada satu faktor lagi yang memiliki pengaruh yang luar biasa terhadap keberhasilan seseorang, yaitu kecerdasan mengatasi masalah atau Adversity Quotient (AQ). Selanjutnya, Sudarman mencoba mengintegrasikan $\mathrm{AQ}$ dalam pembelajaran matematika [2].

Pada penelitian terdahulu seperti yang disebutkan diatas, penelitian hanya terbatas pada pengidentifikasian proses berpikir kritis dalam menyelesaikan permasalahan, pentingnya AQ dalam meraih kesuksesan, dan uji coba pengintegrasian AQ dalam pembelajaran matematika. Oleh karena itu, peneliti merasa perlu untuk melakukan penelitian mengenai bagaimanakah proses berpikir kritis dalam pemecahan masalah pokok bahasan segitiga dan segi empat ditinjau dari Adversity Quotient (AQ).

Berdasarkan uraian di atas, penelitian yang berjudul "Proses Berpikir Kritis Siswa Kelas VII F MTs AL-Qodiri 1 Jember dalam Pemecahan Masalah Matematika Pokok Bahasan Segitiga dan Segi empat ditinjau dari Adversity Quotient (AQ)" ini, dilaksanakan untuk mengetahui proses berpikir kritis siswa kelas VII F MTs AL-Qodiri 1 Jember dalam pemecahan masalah matematika pokok bahasan segitiga dan segi empat ditinjau dari Adversity Quotient $(A Q)$. Hasil penelitian ini diharapkan dapat memberikan informasi dan menambah pengetahuan tentang proses berpikir kritis siswa kelas VII F MTs AL-Qodiri 1 Jember dalam pemecahan masalah matematika pokok bahasan segitiga dan segi empat ditinjau dari Adversity Quotient $(A Q)^{\prime \prime}$.

\section{Metode Penelitian}

Jenis penelitian ini adalah penelitian deskriptif dengan pendekatan kualitatif. Penelitian ini dimaksudkan untuk mendeskripsikan tentang proses berpikir kritis siswa kelas VII F MTs Al-Qodiri 1 Jember dalam pemecahan masalah pada pokok bahasan segitiga dan segi empat ditinjau dari Adversity Quotient. Pada penelitian ini diamati bagaimana proses berpikir siswa climber, camper, dan quitter dalam menyelesaikan permasalahan berdasarkan indikator berpikir 
kritis.

Subjek dalam penelitian ini diambil dengan menggunakan teknik snowball sampling. Subyek yang digunakan dalam penelitian ini sebanyak enam siswa, yaitu 2 siswa climber, 3 siswa camper, dan 1 siswa quitter. Penelitian dilaksanakan pada semester genap 2015/2016. Instrumen yang digunakan untuk mengumpulkan data adalah angket Adversity Qoutient Profile (ARP), tes kemampuan berpikir kritis, dan pedoman wawancara. Metode pengumpulan data yang digunakan dalam penelitian ini yaitu metode angket, tes, dan wawancara. Data yang dianalisis adalah hasil tes kemampuan berpikir kritis dalam pemecahan masalah pokok bahasan segitiga dan segi empat serta hasil wawancara pada setiap subyek. Hal tersebut dilakukan untuk mendeskripsikan proses berpikir kritis siswa dalam pemecahan masalah ditinjau dari Adversity Quotient. Sumber data pada penelitian ini adalah siswa sebagai subjek penelitian.

\section{Hasil Penelitian}

Berdasarkan hasil analisis data terhadap hasil validasi angket dan tes, diperoleh rerata total ( $\mathrm{Va}$ ) angket sebesar 4,83 dan rerata total $(\mathrm{Va})$ tes sebesar 4,67 sehingga angket dan tes termasuk kategori valid. Setelah dilakukan uji validitas, kemudian dilakukan beberapa revisi sesuai dengan saran validator. Tahap selanjutnya yaitu melakukan uji reliabilitas angket dan tes menggunakan rumus alpha. Setelah menganalisa hasil uji coba angket dan tes, diperoleh koefisien reliabilitas angket sebesar 0,764 menunjukan angket termasuk dalam kategori reliabilitas tinggi dan koefisien reliabilitas tes sebesar 0,64 menunjukan tes termasuk dalam kategori reliabilitas tinggi pula sehingga angket dan tes dapat diberikan pada subyek.

Setelah dilakukan pengumpulan data, dipilih enam orang siswa yang mewakili setiap kategori Adversiti Quotient (AQ) sebagai subyek penelitian dengan menggunakan teknik snowball sampling. Berdasarkan hasil analisis yang telah dilakukan, keenam subyek tersebut memiliki cara yang berbeda-beda dalam menyelesaikan permasalahan yang diberikan. hal tersebut terlihat dari bagaimana cara mereka dalam memahami soal, memilah informasi mana yang dibutuhkan dan yang tidak, menarik kesimpulan berdasarkan informasi yang diperoleh, serta merencanakan penyelesaian yang tepat.

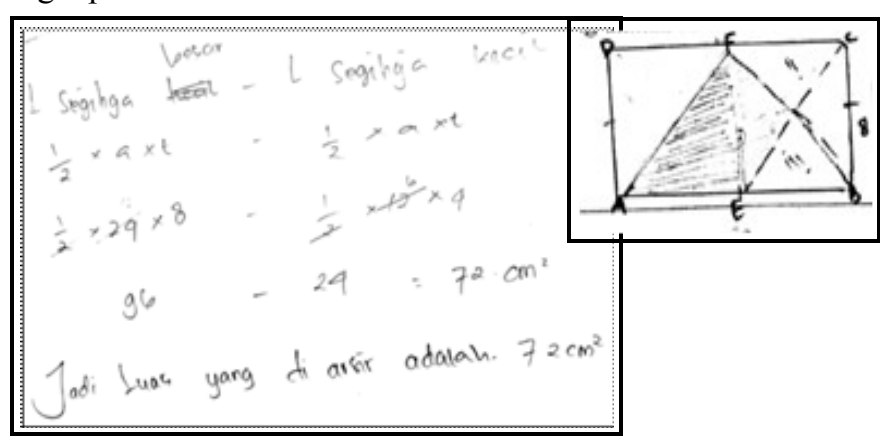

Gambar 1. subyek 1 tahap inferensi dan strategi soal 1

Subyek 1 (siswa climber) mampu menyelesaikan setiap permasalahan yang diberikan dengan teliti dan benar.
Subyek 1 melalui setiap tahapan berpikir kritis dalam menyelesaikan permasalahan yang diberikan, baik tahap klarifikasi, assessment, inferensi, dan strategi. Subyek 1 tergolong memiliki kemampuan berpikir kritis yang baik, hal ini diperkuat oleh jawaban subyek 1 dalam menyelesaikan permasalahan yang diberikan. Subyek 1 mampu menemukan solusi kritis dari permasalahan yang diberikan. Subyek 1 menuliskan solusi pemecahan yang lebih cepat dan tepat serta berbeda dengan subyek yang lain dengan menggunakan bahasanya sendiri seperti yang terlihat pada gambar 1.Berdasarkan Gambar 1, terlihat bahwa untuk menghitung luas $A F O E$, subyek 1 hanya menggunakan dua langkah yaitu mengurangkan luas segitiga $A F B$ dengan segitiga $E O B$. Sedikit berbeda dengan subyek 1, subyek 2 (siswa climber) juga melalui setiap tahapan berpikir kritis dalam menyelesaikan permasalahan yang diberikan, baik tahap klarifikasi, assessment, inferensi, dan strategi. Namun, pada tahap strategi penyelesaian soal no 1 , subyek 2 menggunakan cara biasa dengan menghitung luas setiap bangun untuk memecahkan masalah yang diberikan tanpa memahami konsepnya dengan benar. Sehingga, meskipun jawabannya benar, langkah penyelesaian tersebut kurang efisien. Berikut cuplikan jawaban subyek 2 pada tahap strategi soal 1

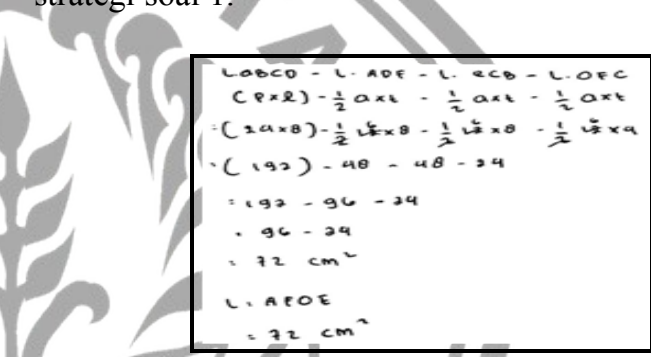

Gambar 2. subyek 2 tahap strategi soal 1 Pada penyelesaian soal no 2 , pada tahap inferensi, subyek 2 menggunakan cara yang berbeda pula dengan subyek lainnya. Subyek 2 menjumlahkan luas segitiga $A E C$ dengan luas segitiga $B C F$ untuk menghitung luas bangun yang diarsir. Meskipun subyek 2 mampu mememukan langkah penyelesaian yang sangat baik namun subyek 2 kurang teliti dalam menyelesaikan langkah pemecahan masalah yang telah ditemukan. Dengan demikian, subyek 2 belum tergolong siswa yang kritis.

Subyek 3, 4, dan 5 (siswa camper) telah menyelesaikan setiap permasalahan yang diberikan meskipun jawabannya kurang tepat. Proses berpikir subyek 3, 4, dan 5 hanya sampai pada tahap assessment. Subyek 3, 4, dan 5 kurang memahami permasalahan yang diberikan dengan baik. Subyek 3, 4, dan 5 juga belum mampu menghubungkan setiap informasi yang diberikan dengan pengetahuan yang telah didapat sebelumnya sehingga solusi pemecahan yang diberikan untuk menyelesaikan setiap permasalahan yang diberikan kurang tepat. Subyek 3 , 4, dan 5 terlalu terburuburu dalam menyelesaikan setipa permasalahan yang diberikan. Hal tersebut sesuai dengan karakteristik siswa dengan AQ sedang (camper) yang cepat merasa puas dengan apa yang mereka kerjakan dan kerap mengabaikan kemungkinan-kemungkinan yang akan didapat. Dengan demikaian, Subyek 3 belum termasuk siswa yang kritis.

Berbeda dengan kelima subyek lainnya, proses berpikir kritis subyek 6 (siswa quitter) dalam upaya memecahkan 
permasalahan yang diberikan terhenti pada tahap klarifikasi. Subyek 6 hanya mampu menyebutkan apa yang diketahui dan apa yang ditanyakan pada soal. Subyek 6 kebingungan saat diminta untuk memilah informasi berdasarkan apa yang ditanyakan pada soal. Hal ini diperkuat dengan hasil wawancara yang telah dilakukan, yaitu subyek 6 memilih diam saat ia ragu dengan jawabannya

\section{Pembahasan}

Berdasarkan hasil pengkategorian AQ berdasarkan skor ARP pada siswa kelas VII F, terlihat bahwa siswa kelas VII F terdiri atas $7,69 \%$ siswa climber, $11,54 \%$ siswa peralihan camper ke climber, 46,15\% siswa camper, 26,92\% siswa peralihan quitter ke camper, dan 7,69\% siswa quitter. Setelah diperoleh hasil pengkategorian AQ tersebut, maka diambil 6 siswa, yaitu 2 siswa climber, 3 siswa camper, dan 1 siswa quitter sebagai subyek penelitian menggunakan tehnik snowball sampling. Keenam subyek tersebut, kemudian diberikan tes kemampuan berpikir kritis pokok bahasan segitiga dan segi empat serta wawancara. Data berupa jawaban siswa dan hasil wawancara selanjutnya dianalisis guna memperoleh kesimpulan penelitian.

Berdasarkan analisis data yang telah dilakukan, terlihat bahwa keenam subyek yang mewakili setiap kategori adversity quotient mampu menyelesaikan permasalahan pokok bahasan segitiga dan segi empat dengan baik. Namun, proses berpikir yang mereka lalui dalam menyelesaikan permasalahan tersebut berbeda-beda.

Pada dasarnya keenam subyek tersebut memahami maksud soal yang diberikan. Meskipun tidak semua subyek menuliskan informasi dalam lembar jawaban dengan lengkap, namun keempat subyek tersebut mampu menyebutkan dengan lisan semua informasi yang diberikan pada soal. Berdasarkan lembar jawaban dari keempat subyek tersebut, tampak bahwa hanya subyek 3 yang menuliskan informasi yang diketahui dan yang ditanyakan pada soal dengan lengkap dan benar. Meskipun demikian, kelima subyek lainnya mampu menyebutkan informasi-informasi tersebut dengan lengkap dan benar, serta menggunakan bahasanya sendiri saat kegiatan wawancara berlangsung. Dengan demikian, dapat disimpulkan bahwa keempat subyek mampu mengklarifikasikan setiap permasalahan yang diberikan dengan baik. Kemampuan mengklarifikasikan permasalahan tersebut dapat dilihat dari informasi apa saja yang dituliskan pada lembar jawaban ataupun penjelasan secara lisan saat wawancara

Setelah subyek mampu mengklarifikasikan setiap permasalahan, tahapan proses berpikir kritis selanjutnya yang harus dilalui adalah tahap assessment. Pada tahap ini, subyek 1, 2, 3, 4, dan 5 sudah mampu menemukan informasi-informasi penting dari soal serta mampu memilah informasi apa saja yang dibutuhkan untuk menyelesaikan setiap permasalahan yang diberikan. Berbeda dengan subyek lainnya, subyek 6 belum mampu melalui tahapan berpikir kritis ini. Subyek 6 belum mampu memilah informasiinformasi yang telah ditemukan pada tahap sebelumnya berdasarkan permasalahan yang berikan. Hal ini diperkuat dengan lembar jawaban dari subyek 4 yang hanya berisi informasi yang diketahui serta apa yang ditanyakan pada tiap-tiap soal.

Tahapan proses berpikir kritis yang ketiga yaitu tahap inferensi. Tahap dimana siswa membuat kesimpulan mengenai langkah yang akan digunakan untuk menyelesaikan permasalahan berdasarkan informasi yang telah diperoleh pada tahap sebelumnya dengan memperhatikan hubungan tiap informasi tersebut. Pada tahap ini, subyek 1 mampu menggambarkan bangun yang dimaksud soal dengan benar, sesuai dengan informasiinformasi yang telah diberikan pada soal. Subyek 1 juga mampu merumuskan solusi kritis dari permasalahan yang diberikan. subyek 1 menggunakan cara yang berbeda dengan subyek lainya. Subyek 1 berhasil menemukan langkah pemecahan masalah yang mudah, cepat dan tepat. Sama halnya dengan subyek 1 , subyek 2 juga mampu menemukan solusi yang tepat untuk menyelesaikan setiap permasalahan yang diberikan. Namun, solusi pemecahan masalah yang digunakan subyek 2 merupakan solusi pemecahan biasa seperti yang pernah ia gunakan pada permasalahan sebelumnya. Berbeda dengan subyek 1 dan 2, subyek 3, 4, dan 5 belum mampu menyimpulkan langkah penyelesaian yang akan digunakan untuk setiap permasalahan dengan benar. Subyek 3, 4, dan 5 belum mampu menggambarkan bangun yang dimaksud pada soal dengan tepat berdasarkan informasi-informasi yang telah diketahui sehingga solusi pemecahan masalah yang digunakan kurang tepat.

Setelah subyek menyimpulkan solusi apa yang akan digunakannya untuk menyelesaikan permasalahan, tahap selanjutnya adalah melaksanakan langkah penyelesaian tersebut dengan teliti sehingga diperoleh solusi penyelesaian masalah yang tepat. Tahap ini dikenal dengan tahap strategi. Subyek 1 dan 2 mampu menyelesaikan langkah pemecahan yang telah ditemukannya dengan baik sehingga diperoleh solusi pemecahan masalah yang tepat. Sedangkan subyek 3, 4, dan 5 belum mampu menemukan solusi pemecahan masalah yang tepat karena subyek 3, 4, dan 5 belum mampu melalui tahap inferensi dengan baik atau belum mampu menyimpulkan langkah pemecahan masalah yang tepat.

Berdasarkan uraian di atas, secara ringkas proses berpikir kritis subyek dalam menyelesaikan permasalahan sub pokok bahasan segitiga dan segi empat dapat dilihat pada tabel 1 .

Tabel 1 Proses Berpikir Kritis Subyek dalam Menyelesaikan

\begin{tabular}{|c|l|c|c|c|}
\hline $\begin{array}{c}\text { Tahapan } \\
\text { Berpikir } \\
\text { Kritis }\end{array}$ & \multicolumn{1}{|c|}{ Indikator } & Climber & Camper & Quitter \\
\hline Klarifikasi & $\begin{array}{l}\text { Siswa mampu } \\
\text { menyebutkan } \\
\text { informasi yang } \\
\text { diketahui dalam } \\
\text { permasalahan. }\end{array}$ & $\sqrt{ }$ & $\sqrt{ }$ & $\sqrt{ }$ \\
\cline { 2 - 5 } & $\begin{array}{l}\text { Siswa mampu } \\
\text { menyebutkan } \\
\text { pertanyaan yang } \\
\text { diajukan dalam } \\
\text { permasalahan. }\end{array}$ & $\sqrt{ }$ & $\sqrt{ }$ & $\sqrt{ }$ \\
\hline
\end{tabular}




\begin{tabular}{|c|c|c|c|c|}
\hline $\begin{array}{c}\text { Tahapan } \\
\text { Berpikir } \\
\text { Kritis }\end{array}$ & Indikator & Climber & Camper & Quitter \\
\hline Assessment & $\begin{array}{l}\text { Siswa mampu } \\
\text { memilah } \\
\text { informasi yang } \\
\text { dibutuhkan dan } \\
\text { yang tidak } \\
\text { dibutuhkan dalam } \\
\text { pemecahan } \\
\text { masalah. }\end{array}$ & $\sqrt{ }$ & $\sqrt{ }$ & \\
\hline \multirow[t]{2}{*}{ Inferensi } & $\begin{array}{l}\text { Siswa mampu } \\
\text { menggunakan } \\
\text { informasi- } \\
\text { informasi yang } \\
\text { relevan dalam } \\
\text { permasalahan } \\
\text { atau pengetahuan } \\
\text { sebelumnya yang } \\
\text { ia peroleh untuk } \\
\text { menyelesaikan } \\
\text { permasalahan } \\
\text { tersebut. }\end{array}$ & $\sqrt{ }$ & & \\
\hline & $\begin{array}{l}\text { Siswa mampu } \\
\text { menjelaskan } \\
\text { bagaimana } \\
\text { hubungan tiap } \\
\text { informasi yang } \\
\text { ada. } \\
\text { Siswa mampu } \\
\text { menemukan } \\
\text { langkah untuk } \\
\text { menyelesaikan } \\
\text { permasalahan }\end{array}$ & & & \\
\hline Strategi & $\begin{array}{l}\text { Siswa mampu } \\
\text { menjelaskan } \\
\text { dengan baik } \\
\text { langkah } \\
\text { pemecahan } \\
\text { masalah yang } \\
\text { sudah ditemukan. }\end{array}$ & & & \\
\hline
\end{tabular}

\section{Kesimpulan dan Saran}

Berdasarkan penelitian yang telah dilakukan dari awal hingga akhirnya melakukan analisis data hasil penelitian tentang proses berpikir kritis siswa dengan AQ tinggi (climber), AQ sedang (camper), dan AQ rendah (quitter), maka diperoleh kesimpulan sebagai berikut:

1. Proses Berpikir Kritis Siswa dengan AQ Tinggi (Climber)

Proses berpikir siswa dengan AQ tinggi (climber) dalam menyelesaikan setiap permasalahan sedikit berbeda dengan siswa lainnya. Proses berpikir siswa dengan AQ tinggi (climber) dalam pemecahan masalah memenuhi ke empat tahapan proses berpikir kritis yaitu klarifikasi, assessment, inferensi, dan strategi. Pada tahap klarifikasi, siswa dengan AQ tinggi mampu menyebut informasi yang diketahui dan yang ditanyakan dengan benar. Tahap assessment, siswa dengan AQ tinggi mampu memilah setiap informasi yang dibutuhkan dan yang tidak dibutuhkan untuk menyelesaian setiap permasalahan. Tahap inferensi, siswa dengan AQ tinggi mampu mengunakan informasi yang relevan untuk menyelesaikan permasalahan dan mampu menjelaskan hubungan tiap informasi dengan menggunakan bahasanya sendiri. Pada tahap strategi, siswa dengan AQ tinggi mampu menemukan solusi kritis dan menyelesaikan langkah pemecahan masalah dengan teliti dan benar. Hal tersebut sesuai dengan karakteristik siswa dengan AQ tinggi yang memiliki sifat ulet, gigih, dan memiliki keberanian untuk mengunakan solusi pemecahan masalah yang berbeda dengan siswa lainnya. Dengan demikian, uraian di atas menunjukkan bahwa siswa dengan AQ tinggi termasuk siswa yang kritis.

2. Proses Berpikir Kritis Siswa dengan AQ sedang (Camper)

Proses berpikir siswa dengan AQ sedang (camper) dalam menyelesaikan permasalahan hanya memenuhi dua tahapan proses berpikir kritis yaitu klarifikasi dan assessment. Meskipun, siswa denga $\mathrm{AQ}$ sedang mencoba menyelesaikan setiap permasalahan yang diberikan. Pada tahap inferensi siswa masih kebinggungan dan belum mampu menggunakan pengetahuan yang telah dimiliki sebelumnya untuk mengambarkan bangun dari beberapa informasi yang telah diketahui. Siswa dengan AQ sedang juga kurang memamami masalah yang diberikan dengan seksama sehingga mereka belum mampu menemukan solusi penyelesaian yang tepat. Hal tersebut sesuai dengan karakteristik siswa dengan AQ sedang yang cepat merasa puas dengan apa yang mereka kerjakan dan kerap mengabaikan kemungkinan-kemungkinan yang akan didapat. Dengan demikian, uraian diatas menunjukkan bahwa siswa dengan AQ sedang bukan termasuk siswa yang kritis.

3. Proses Berpikir Kritis Siswa dengan AQ rendah (Quitter)

Proses berpikir siswa dengan $\mathrm{AQ}$ rendah (quitter) dalam menyelesaikan permasalahan yang diberikan hanya memenuhi tahap klarifikasi dalam tahapan proses berpikir kritis. Terdapat 2 soal yang diberikan dan siswa dengan AQ rendah (quitter) hanya menuliskan informasi apa yang diketahui dan apa yang ditanyakan dalam soal tanpa mencoba untuk menyelesaikan permasalahan yang diberikan. Hal ini sesuai dengan karakteristik siswa dengan $\mathrm{AQ}$ rendah (quitter) yang mudah menyerah ketika menemukan kesulitan dan berhenti tanpa dibarengi usaha sedikitpun. Dengan demikian, uraian diatas menunjukkan bahwa siswa dengan $\mathrm{AQ}$ rendah bukan termasuk siswa yang kritis. 
Adapun beberapa saran yang dapat diberikan berdasarkan penelitian ini yaitu:

1. Kepada Guru, untuk membiasakan siswanya mengerjakan soal dengan rinci, tahap demi tahap, sehingga diharapkan dapat meningkatkan ketelitian siswa. Selain itu, memberikan latihan soal yang dapat mengembangkan kemampuan berpikir kritis siswa dan selalu mengingatkan siswanya untuk memahami setiap permasalahan dengan seksama sehingga mampu menyelesaikan setiap permasalahan dengan baik.

2. Kepada Siswa, hendaknya memahami permasalahan yang diberikan seksama dan lebih teliti dalam menyelesaikan setiap permasalahan yang ada.

3. Kepada Peneliti lain, untuk melakukan penelitian lebih lanjut dengan menggunaka subyek yang sama namun variabel bebas dan variabel terikatnya berbeda atau subyek berbeda dengan variabel bebas dan variabel terikatnya sama. Dengan demikian, terdapat beragam penelitian yang berguna untuk mengetahui proses berpikir kritis siswa dalam menyelesaikan permasalahan dan mampu mengembangkan kemampuan berpikir kritis siswa

4. Meskipun angket sudah valid dan koefisien reliabilitas angket termasuk kategori tinggi, namun ada beberapa ketidaksesuaian hasil dengan pendapat guru. Hal ini diakibatkan oleh beberapa siswa yang menganggap bahwa kode negatif pada soal menunjukan skor negatif pula. Sehingga, sebaiknya untuk peneliti lain yang ingin menggunakan angket yang sama, kode soal tidak perlu dicantumkan.

5. Mencari literature sebanyak-banyaknya memperkuat teori.

\section{Ucapan Terima Kasih}

Penulis mengucapkan terima kasih kepada dosen pembimbing tugas akhir, serta kepala sekolah dan guru matematika di Mts Al-Qodiri 1 Jember yang telah membimbing selama penelitian.

\section{Daftar Pustaka}

[1] Ambarawati, S., Mardiana, dan Subanti, Sri. 2014. Profil Berpikir Kritis Siswa Kelas VIII SMP Negeri 3 Surakarta dalam Memecahkan Masalah Pokok Bahasan Sistem Persamaan Linear Dua Variabel (SPLDV) ditinjau dari Kecerdasan Majemuk dan Gender. Jurnal Elektronik Pembelajaran Matematika. ISSN: 23391685. Vol.2 (9): 984-994. [online].Tersedia : http://www.jurnal._ fkip.uns.ac.Id/ index.php/s2math/article/view/483

[2] Bennu, Sudarman. 2012. Adversity Quotient: Kajian Kemungkinan Pengintegrasian dalam Pembelajaran Matematika. AKSIOMA Jurnal Pendidikan Matematika. [online]. Tersedia: http://jurnal. untad.ac.id/jurnal/index.php/AKSIOMA/article/view/1279

[3] Fisher, Alec. 2009. Berpikir Kritis : Sebuah Pengantar. Jakarta: Erlangga

[4] Jacob, S. M ; Sam, H. K. 2008. Measuring Critical Thinking In Problem Solving Through Online Discussion Forums In First Year University Mathematics. International MultyConference of Engineers and Computer Scientists. ISBN 978-988-98671-8-8. Vol 1. [online]. Tersedia: www.iaeng.org/publication/IMECS2008/ IMECS2008 pp816-821.pdf

[5] Limardani, G. , Analisis Kesulitan Siswa dalam menyelesaikan Soal Aljabar Berdasarkan Teori Pemahaman Skemp Pada Siswa Kelas VIIID SMP Negeri 4 Jember. Jember : Repository UNEJ

[6] Stoltz, Paul. 2007. Mengubah Hambatan Menjadi Peluang Faktor Faktor Paling Penting Dalam Meraih Sukses Adversity Quotient. Jakarta: Gramediasarana Indonesia

[7] Suryanti, Oktarica Cindra. 2015. Identifikasi Berpikir Kritis dalam Pemecahan Masalah Matematika Pokok Bahasan Garis dan Sudut pada Siswa Kelas VII-E SMP Negeri 4 Jember. Tidak Diterbitkan. Skripsi, Jember: Program Studi Pendidikan Matematika Universitas Jember. 